\title{
Impact of Punjab Rural Support Program on Poverty Alleviation: Case Study of District Mandi Bahauddin
}

\author{
Muhammad Tahir ${ }^{1}$, Bashir Ahmad Khilji², Syed Waqar Hussain ${ }^{3}$, \\ Irfan Hussain ${ }^{4}$
}

\begin{abstract}
The present study is an attempt to examine the impact of micro credit facility provided by Punjab Rural Support Program (PRSP) in rural areas of Mandi Bahauddin, Punjab. A convenient sampling technique has been used to select a sample of one hundred respondents. Pre - structured questionnaire has been used to collect data related to various aspects of the program. Micro credit taken, family size, nature of employment of the respondent, and level of education are the key variables of the collected data. Income differential is used to measure the effectiveness of the PRSP's micro finance program. It is calculated as income after micro credit and income before micro credit. Two econometrics models have been developed. Standard econometrics techniques have been used to estimate these models. The estimated results show that micro finance plays a vital role in the enhancement of borrowers' income and hence alleviate poverty in the study area. Level of education, family size, and nature of employment are also the major determinants of income differential and poverty measures. Validity of the estimates have been checked using various econometric tests and alternate procedures are adopted wherever estimates are not in conformity to econometric rules. On the basis of the evidence collected, this study has suggested that to make the program more responsive, it is imperative that the interest rate be reduced, loan size and procedures be rationalized, product range of the scheme be diversified, and recovery procedure may be made very convenient.
\end{abstract}

Keywords: Micro-credit, PRSP, education, poverty.

\section{Introduction}

The origin of the word "poverty" is the word 'poor', and a 'poor', according to UNDP report (2010), is a person if he or she gets US $\$ 1.25$ per day. The report elaborates that this amount is not sufficient to enable a person get the desired calories required for a day work. Poverty has been in the list of core issues in less developed countries (LDCs) since long. Poverty can be defined as the deficiency of basic hu-

1 MPhil Scholar, Preston University Kohat - Islamabad Campus

2 Prof. and HoD, Department of Economics, Preston University Kohat - Islamabad Campus

3 Assistant Professor, Institute of Management Sciences, Peshawar. Email: waqar.hussain@imsciences. edu.pk

4 PhD scholar, GC University Faisalabad. 
man needs such as food, drinking water, education, sanitation, health facilities and shelter etc.

Governments of under developed countries (UDCs) have particularly been conscious to alleviate poverty. Rural Support System has been termed as one appropriate remedy to overcome this menace. The Rural Support Programs (RSPs) have been started in many countries of the world including Pakistan. The RSPs have been recognized as the best approach for poverty alleviation. It has improved the standard of living of the rural people by a greater extent. The effectiveness of RSPs can be judged by its large number of beneficiaries across the developing world, which is almost 67.6 million. The assessment of Asian Development Bank has been substantiated by Manzoor and Saira (2006) who recognized microfinance as an effective tool of poverty reduction in Pakistan.

Poverty has affected a great segment of the population of Pakistan too. There are different estimation techniques for the measurement of poverty. Ministry of finance, Pakistan has developed a new approach, known as Cost of Basic Need (CBN) approach, to measure poverty in Pakistan. A new poverty line, for a pattern of consumption of reference group, is estimated to be Rs 3030 per adult, per month as per Household Integrated Economic Survey (HIES) for the year of 2013-14. According to this new methodology, 29.5 percent of the population is estimated to live below poverty line which amounts to total of 55 million people as per 2013-14 estimated population of 186.2 million. (Economic Survey of Pakistan, 2015-16)

Micro credit is the financial support to poor people to finance their private businesses and empower them economically. It encourages low income groups to sum up their resources for the achievement of their business goals. Poor people are normally constrained by a lack of financial resources. This is a strategy to engage them in self-employed processes for the effective utilization of resources. Population in Pakistan is increasing rapidly, whereas resources are not coping with such growth to meet the demands of honorable living. It is, therefore, binding that family size should be paid due attention. Micro credit, self-employment, and family size are the essential components of affecting disposable income, and help to alleviate mass poverty.

Rural poverty reduction is considered a key to sustainable development worldwide; therefore, it is important to investigate that whether Punjab Rural Support Program (PRSP) has extended micro credit facilities in the rural district Mandi Bahauddin or not? There are several reasons which motivated us to select Mandi Bahauddin as the study area. Majority of its population lives in the rural areas and depend on agriculture and livestock. PRSP is the oldest community based organization which has been involved in the micro-finance facility in this district. This study has par- 
ticularly focused on questions like, has PRSP's micro credit helped in rural poverty alleviation? Whether PRSP's micro credit program has been sustainable for poor and marginalized segments of the society? These questions have not been answered in the body of research literature. The present study is an attempt to answer these questions. The empirical results of this study can be used to design development policy in the selected area of the study. The major objectives of the study include:

a. To examine the role of PRSP's micro credit provision in poverty alleviation in Mandi Bahauddin District.

b. To suggest some policy guideline in the light of results of the study.

\section{Review of Literature}

Schultz (1964) while explaining the causes of rural poverty in developing countries argued that traditional means of cultivation have been the main source of poverty in these countries. He explained that these traditional means could not be used to expand agriculture productivity as predicted by increasing return theory. He suggested that rural poverty can be reduced by modernizing agriculture sector, introducing high yield seeds, and increased use of fertilizers and pesticides, brining land reforms, redistributing the land, and improving irrigation system. Hussain and Shirazi (1995) evaluated the use of 'infaq' as a major cause of the poverty status of a household. He revealed that the probability of being poor increases if household size increases. The same probability is negatively related to the educational level and number of earners in a household.

Adams and $\mathrm{He}$ (1995) examined the rural income inequality in Pakistan. They identified certain main sources of this income, namely, farm, non-form, livestock, and transfer and rental sources. The study pointed out that government employment and production of cash crop pull the income inequality in upward direction; whereas, non-farm livestock, unskilled labour, production of food crop are the major forces that pull the income inequality downward.

Hulme and Mosley (1996) quantified the impact of micro finance on poverty reduction in four countries, namely, Indonesia, India, Bangladesh, and Sri Lanka. They estimated growth rates of income for both borrowers and non-borrowers. They revealed that the growth of borrower's income is faster than the growth of control group's income. They concluded that micro finance is an effective tool for poverty alleviation. Kemal (1995) studied the state of poverty alleviation mechanism in Pakistan. He concluded that tax policies of the Government are the main hurdles in poverty alleviation process. 
Amjad and Kemal (1997) studied the impact of macroeconomic variables on rural poverty in Pakistan. They assessed various structural adjustment policies and concluded that poverty is a direct outcome of such policies. They further highlighted that unfair distribution of land or inequality of land holding is the cause of absolute poverty.

Khandker, Samad, and Khan (1998) studied the role of micro-finance programs in poverty alleviation in Bangladesh. They analyzed the case of Grameen Bank, Bangladesh Rural Advancement Committee (BRAC) and Bangladesh Rural Development Board (BRDB). The principal evidences revealed that income, production, and employment increased in response to these projects, especially in non-farm sector of rural Bangladesh.

Panjaitan-Driodisuryo and Cloud (1999) examined the relationship between micro credit and self-employment in Indonesia. They studied the particular role of Small Farmers Development Program (SFDP) and concluded that it has been effective in training poor women. They also concluded that training the of SFDP and the credit facility of Bank Rakyat Indonesia (BRI) enabled the poor to earn income through a number of economic activities related to trading, handicraft, and weaving traditional clothes. Waheed (2001) studied the role of micro credit offered by Punjab Rural Support Programs (PRSPs) in uplifting poor and marginalized segment of the society. He concluded that 86.7 percent of respondents enjoy better quality of life as a result of borrowing from PRSP. The PRSP credit facility helped to expand businesses of 49.2 percent of the sampled respondents, while 19.2 percent established their businesses who previously were not self-employed.

Siddiqui (2001) examined the contribution of women in economic activities and poverty alleviation in Pakistan. She revealed that the major determinant of women productivity is education and health status. Chaudhry (2003) analyzed the status of Bahawalpur district with respect to poverty. He concluded that infrastructure development, more agricultural production, development of non-farm or traditional rural economy, better quality of life, and educational and health facilities are the major determinants of rural poverty in the district. Anwar, Qureshi, and Ali (2004) investigated the impact of unfair distribution of rural agricultural land and poverty in Pakistan. They reported that rural poverty is highly dependent on the unequal distribution of cultivable land which slows down the trickledown effect of growth of productivity in the agriculture sector on poverty alleviation.

Sabir (2004) investigated the principal determinants of poverty of small farmers in Pakistan. He found less farm output, larger family size along with high dependency ratio, less education of the head of the household, and lack of appropriate infrastructure as driving factors which push the poverty upward in small farmers of Pakistan. 
However, a regular supply of fertilizers and its low purchase prices, availability of irrigation water, and off farm employment opportunities are those factors which pull the incidence of poverty down among the people.

Parker, Kirkpatrick, and Theodorakopoulou (2008) studied the relationship between Infrastructure Regulations (IRs) and poverty reduction in Developing Countries (DCs). The study concluded that improvement in the infrastructure quality leads to an increase in the efficiency. It also decreased the cost of production which ultimately leads to an increase in the agriculture output.

Chaudhry (2009) probed for the poverty reduction programs in Southern Punjab of Pakistan. He concluded that micro finance was the potent tool for poverty alleviation. He, however, emphasized that these programs could be more effective if macro-economic stability is ensured.

Saboor, Hussain, and Munir (2009) examined the association between micro-credit and poverty alleviation in Pakistan. They found evidence in favor of the micro-credit which could increase income of the borrower in the study area.

Shirazi and Khan (2009) explained that Pakistan Poverty Alleviation Fund (PPAF) has reduced the overall poverty level in Pakistan. Borrowers have enjoyed higher income during the study period. Similarly, Waheed (2009) also concluded that micro-credit along with education are the basic tools to generate higher income and reduce poverty in rural areas of Punjab. Nawaz (2010) undertook the same analysis for Bangladesh and proved it to be an important tool to alleviate poverty. Noreen (2010), and Akram and Hussain (2011) studied the impact of micro-finance on poverty. They concluded that micro-finance could be helpful in poverty alleviation.

Noreen (2010), and Akram and Hussain (2011) studied the impact of micro-finance on poverty. They concluded that micro-finance could be helpful in poverty alleviation. While carefully analyzing the relevant literature, there are several issues which have not been properly analyzed. First, the role of Punjab Rural Support program (PRSP) in poverty reduction has been investigated while considering borrower's current income as a benchmark for poverty. However, micro-finance is helpful if it can enhance income differential, i.e. income after micro-finance and income before micro-finance. Similarly, micro-finance is effective if it can pull the borrower out of the poverty trap. Studies related to the development of such poverty measures are scant to probe various aspects of the problem. Secondly, PRSP interventions in poverty reduction in Mandi Bahauddin has also not been properly addressed. The present study is an attempt to fill the above research gap.

\section{Methodology}


We have modified the model adopted by Waheed (2009). The impact of micro-finance program is judged by examining the difference between the income before and after micro-finance program. Moreover, some determinants, other than micro-credit not analyzed by Waheed, have been incorporated to explain the spread in income. We have developed following version of the model.

$$
\Delta I=\beta_{0}+\beta_{1} M F+\beta_{2} F_{-} \text {Size }+\beta_{3} E m p+\beta_{4} E d u+u
$$

Where " $\Delta I$ " is the log of difference of income before and after micro-finance, "MF" is the log of amount of micro-finance taken by an individual, "F_Size" is the family size of the borrower, "Edu" is the years of schooling, and "Emp" is the dummy for employment status, i.e. it is equal to 1 if an individual is self-employed and zero otherwise. If an individual is educated with small family size and has borrowed a sufficiently large amount of loan, then it is expected that his income after micro-finance will be greater than the income before micro-finance. It is possible that micro-finance facility may not reduce poverty to the desirable extent due to inappropriate use of funds. In this context, income differential may exist but it may be less. It is in this context, that the following version of the model is also estimated.

$$
D_{-} Y=\alpha_{0}+\alpha_{1} M F+\alpha_{2} F \_ \text {Size }+\alpha_{3} E m P+\alpha_{4} E d u+u
$$

Where "D_Y" is a dummy variable whose value equals 1 if the individual's income differential (the difference in post microfinance income and pre microfinance income) is greater than the average income differential for the whole sample, and zero otherwise. If the individual's income differential is greater than the average income differential for the whole sample, it means that micro-finance has worked in raising the income level above the average income. Both the models are aimed to find out the impact of micro-credit on the income differential controlling for few other factors which are not undertaken by Waheed (2009) in his study.

PRSP micro-financing has mostly been concentrated in Human Resource Development (HRD) to the extent of number of people in Mandi Bahauddin areas. A list of all these borrowers along with their home addresses had been taken from PRSP's zonal offices. A convenient based sample of 100 respondents was selected from Mandi Bahauddin, i.e. only those borrowers were contacted who were economically viable in terms of time and money use. A well-structured questionnaire was designed to collect data related to various socio and economic aspects. A pilot study, restricted to 25 individuals, was also undertaken to determine the response rate of the respondents.

\section{Analysis and Results}

The sample is composed of 70 percent male and 30 percent female respondents. 
A total of 49 percent, both male and female, are in the age group of 30 to 35 years. Micro-finance facility is concentrated in the same age group (Table 1).

Table 1: Gender and Age Distribution of the Respondents

\begin{tabular}{|c|c|c|c|c|c|c|}
\hline \multirow{2}{*}{ Gender } & \multicolumn{2}{|c|}{ Gender Distribution } & \multicolumn{3}{c|}{ Age Distribution } & \multirow{2}{*}{ Total } \\
\cline { 2 - 6 } & Number & Percent & $30-35$ & $35-40$ & $40-55$ & \\
\hline Male & 70 & $70 \%$ & 35 & 25 & 10 & 70 \\
\hline Female & 30 & $30 \%$ & 14 & 10 & 6 & 30 \\
\hline Total & 100 & 100 & 49 & 35 & 16 & 100 \\
\hline
\end{tabular}

Our analysis reveals that 23.23 percent of the borrowers have a family size of five people and about 16 percent have eight children (Table 2). Interestingly, 50 percent of the borrowers are self-employed (Table 3). The study reveals that the literacy rate is 81.2 percent which is higher than the national literacy rate of 65 percent. However, there are respondents who had not completed their primary education. The net literacy rate is 74.75 percent after excluding those who had not completed their primary education. (Table 4).

Table 2: Frequency Distribution of Family Size

\begin{tabular}{|c|c|c|c|c|}
\hline Value & Count & Percent & Cum: count & Cum: percent \\
\hline 3 & 17 & 17.17 & 17 & $17 . .17$ \\
\hline 4 & 9 & 9.09 & 26 & 26.26 \\
\hline 5 & 23 & 23.23 & 49 & 49.49 \\
\hline 6 & 13 & 13.13 & 62 & 62.63 \\
\hline 7 & 13 & 13.13 & 75 & 75.76 \\
\hline 8 & 16 & 16.16 & 91 & 91.92 \\
\hline 9 & 5 & 5.05 & 96 & 96.97 \\
\hline 10 & 3 & 3.03 & 99 & 100.00 \\
\hline & 99 & 100 & 99 & 100.00 \\
\hline
\end{tabular}

Table 5 shows descriptive statistics of the selected variables. Average income's differential ${ }^{5}(\Delta I)$, i.e. income after and before micro-finance is Rs. 2,221.1 which means that the income of borrowers has increased by this magnitude. The average amount of micro-finance $(\mathrm{MF})^{6}$ is given by Rs.13,106 with a standard deviation of Rs. 4,233.3. The average family size is 5.8 , ranging from 3 to 10 . The table also shows level of

5 Estimates of income differential are not expressed in terms of logs. " $\Delta \mathrm{Y}$ " = income after micro credit income before micro credit. Moreover, these estimates are calculated on a per month basis after micro-finance is obtained and business has started.

6 Estimates of amount of micro-finance are not expressed in terms of log. 
Table 3: Nature of Employment Level

\begin{tabular}{|c|c|}
\hline Nature of Employment & Frequency \\
\hline Government & 11 \\
\hline Semi - Government & 18 \\
\hline Private & 21 \\
\hline Self - Employment & 50 \\
\hline Total & 100 \\
\hline
\end{tabular}

Table 4: Distribution of Years of Schooling (Level of Education)

\begin{tabular}{|c|c|c|c|c|}
\hline Value & Count & Percent & Cum: count & Cum: percent \\
\hline 0 & 18 & 18.18 & 18 & 18.18 \\
\hline 2 & 6 & 6.06 & 24 & 24.24 \\
\hline 3 & 1 & 1.01 & 25 & 25.25 \\
\hline 5 & 23 & 23.23 & 48 & 48.48 \\
\hline 8 & 12 & 12.12 & 60 & 60.61 \\
\hline 10 & 9 & 9.09 & 69 & 69.70 \\
\hline 12 & 21 & 21.21 & 90 & 90.91 \\
\hline 14 & 9 & 9.09 & 99 & 100.00 \\
\hline Total & 99 & 100 & 99 & 100 \\
\hline
\end{tabular}

Table 5: Descriptive Statistics of Selected Variables

\begin{tabular}{|c|c|c|c|c|c|}
\hline Variable & $\Delta \mathbf{I}$ & $\mathbf{M F}$ & F_Size & Emp & Edu \\
\hline Mean & Rs 2,221.07 & Rs 13,106.0 & 5.8 & 0.6 & 7.01 \\
\hline Median & Rs 1,750.0 & Rs 12,000.0 & 6.0 & 1 & 8 \\
\hline Maximum & Rs 9,000.0 & Rs 30,000.0 & 10.0 & 1 & 14 \\
\hline Minimum & Rs 800.0 & Rs 10,000.0 & 3.0 & 0 & 0 \\
\hline Std. Deviation & Rs 1,545.4 & Rs 4233.3 & 1.1 & 0.50 & 4.8 \\
\hline $\begin{array}{c}\text { Jarque - Bera } \\
\text { Test }\end{array}$ & 618.1 & 362.7 & 4.8 & 16.6 & 7.3 \\
\hline Probability & 0.00 & 0.000 & 0.13 & 0.000 & 0.02 \\
\hline
\end{tabular}

education of the sampled area. Mean years of schooling is 7.01, ranging from 0 to 14 .

The regression results are reported in Table 6. It is evident from the results that only the coefficient of family size is insignificant. The coefficient of micro-finance is positive and highly significant. Its value is 1.69 which shows that the borrower's income 
is highly elastic, i.e. if micro-finance increases by one percent, income increases by 1.69percent which in turn implies that micro-finance is helpful in poverty alleviation.

The coefficient of dummy variable for the status of employment is also positive and significant. The estimates, given in Table 6 , show that a self-employed borrower's

Table 6: Estimated Results of Model 1 Using OLS

\begin{tabular}{|c|c|c|c|c|}
\hline Variable & Coefficient & Std. error & t-stats & Prob: \\
\hline Constant & -8.77 & 0.68 & -13.08 & 0.0000 \\
\hline MF & 1.61 & 0.07 & 25.28 & 0.0000 \\
\hline F_size & 0.008 & 0.03 & 0.25 & 0.8041 \\
\hline EmPp & 0.21 & 0.11 & 2.92 & 0.0044 \\
\hline Edu & 0.02 & 0.007 & 2.34 & 0.0215 \\
\hline R2 $=0.93$, Adjusted R2 $=0.92$, F statistic $=315.32$, Prob $=0.000$ \\
\hline
\end{tabular}

income rises by 0.29 points more than a person who is not self-employed. The effect of years of schooling on borrower's income differential is also positive and significant. The size of its impact is 0.016 , which means that a one-year schooling adds to the income differential by 0.016 points. R-Square of the model is 93 percent which is very high and indicates a good fit. The estimated results are in accordance with earlier studies in Pakistan such as Amjad and Kemal (1997), Malik and Nazli (1999) and Waheed (2001).

The diagnostic tests indicate that estimates suffer from heterosecdasticity. The values of Breusch-Pagan-Godfrey \& Chi-square are 3.56 and 13.04 respectively with smaller probability values which lead us to reject the null hypothesis of no heteroscedasticity. The value of Jargue-Bera test is 4.81 with a p-value of 0.08 which shows that the residuals are not normally distributed. Table 7 is constructed to estimate model (1) using weighted least squares (WLS) method for a weight of "MF-0.5" as micro-finance is suspected to be a variable which may give rise to heteroscedasticity. Interestingly, the estimated results are similar to our existing results.

Standard errors are larger than usual if there is heteroscedasticity which in turn make inferences inconsistent. White's Heterosecdasticity Consistent Standard Errors and Covariace (WHCS-EC) techniques have been employed to rectify these issues. The values of coefficients remain unchanged; the values of standard errors, however, have been changed along with their probabilities (Table 8).

The estimated results of equation (2) are given in Table 9. The estimated technique is Maximum Likelihood Binary Logit (MLBL). The estimated results are similar to 
Table 7: Estimated Results of Model 1 using WLS [Weights: MF ${ }^{0.5}$ ]

\begin{tabular}{|c|c|c|c|c|}
\hline Variable & Coefficient & Std. error & t-stats & Probability \\
\hline Constant & -8.88 & 0.69 & -12.97 & 0.0000 \\
\hline MF & 1.71 & 0.07 & 24.88 & 0.0000 \\
\hline F_size & 0.008 & 0.021 & 0.26 & 0.78 \\
\hline Emp & 0.21 & 0.11 & 2.92 & 0.005 \\
\hline Edu & 0.02 & 0.007 & 2.33 & 0.03 \\
\hline R2 $=0.928$, Adjusted R2 $=0.925$, F test $=305.70$, Prob $=0.000$ \\
\hline
\end{tabular}

Table 8: Estimated Results of Model 1 using White's Heteroskedasticity-Consistent Standard Errors \& Covariance

\begin{tabular}{|c|c|c|c|c|}
\hline Variable & Coefficient & Std. error & t-stats & Probability \\
\hline Constant & -8.762814 & 0.676616 & -12.95094 & 0.0000 \\
\hline MF & 1.694053 & 0.067223 & 25.20046 & 0.0000 \\
\hline F_size & 0.007289 & 0.027320 & 0.266795 & 0.7902 \\
\hline Emp & 0.297892 & 0.102528 & 2.905472 & 0.0046 \\
\hline Edu & 0.015679 & 0.005978 & 2.622944 & 0.0102 \\
\hline R2 $=0.93$, Adj. R2 $=0.92$ &
\end{tabular}

Table 9: Estimated Results of Model 2 using ML - Binary Logit

\begin{tabular}{|c|c|c|c|c|}
\hline Variable & Coefficient & Std. error & t-stats & Probability \\
\hline Constant & -51.27934 & 19.34393 & -2.650926 & 0.0080 \\
\hline MF & 5.286174 & 1.968157 & 2.685850 & 0.0072 \\
\hline F_size & 4.587612 & 2.195624 & 2.089434 & 0.0367 \\
\hline Emp & 0.708848 & 0.588489 & 1.204522 & 0.2284 \\
\hline Edu & 0.334491 & 0.148046 & 2.259363 & 0.0239 \\
\hline \multicolumn{5}{|l}{ McFadden R-squared $=0.384330$}
\end{tabular}

previous model in terms of the signs of the coefficients. However, the magnitude of impact is different than the first model. The coefficient of micro-finance is still positive with a value of 5.287 , which is highly significant as well. Family size has a positive and significant coefficient. It may be due to the child labor, where more children mean more income. However, unlike the previous model, status of employment does not appear to be significant, but still has a positive coefficient. Education too is positive and significant. This implies that education plays its due role in income generation, which in turn, reduce poverty. The value of McFadden R-Squared is given instead of 
simple R-Squared, which is not applicable in MLBL models. Its value is 38 percent which is fairly high for such qualitative response variable regression model.

\section{Conclusion}

Results of this study reveal that microfinance has a positive impact on income differential and poverty reduction. Education also positively affected income generation, and hence reduced poverty in the study area. However, the impact of status of employment and family size on income generation is mixed. Nature of employment positively and significantly affects income differential; whereas, the model with specific poverty measure insignificantly affects income generation, though positively. It means that if a borrower is self-employed, he is likely to generate more income than a borrower who is employed in a government, semi government, or private sector. Family size does not bear any significant impact on the income differential. However, its coefficient is positive and significant in increasing the borrower's income differential above the sample income differential. It means that larger family size is likely to be better off than those borrowers who have smaller family size. This may be due to the child labor, i.e. children working in fields, shops and other income generating activities, particularly, families with more children are better off in peak times of agriculture activities where labor supply becomes short.

On the basis of the evidence collected, this study suggests that to make the program more responsive, it is imperative that the interest rate be reduced, loan size and procedures be rationalized, product range of the scheme be diversified, and recovery procedure may be made very convenient.

\section{References}

Adams, R., \& He, J. J. (1995). Sources of income inequality and poverty in rural Pakistan. Research Report (International Food Policy Research Institute No.168).

Akram, M., \& Hussain, I. (2011). The role of microfinance in uplifting income level: A study of district Okara-Pakistan. Interdisciplinary Journal of Contemporary Research in Business, 2(11), 83-94.

Amjad, R., \& Kemal, A. R. (1997). Macroeconomic policies and their impact on poverty alleviation in Pakistan. The Pakistan Development Review, 36 (1), 39-68.

Anwar, T., Qureshi, S. K., \& Ali, H. (2004). Landlessness and rural poverty in Pakistan. The Pakistan Development Review, 43(4), 855-874.

Chaudhry, I. S. (2003). An empirical analysis of the determinants of rural poverty in Pakistan: A case study of Bahawalpur district with special reference to Cholistan. Unpublished Ph.D. Thesis, The Islamia University of Bahawalpur, Pakistan 
Chaudhry, I. S. (2009). Poverty alleviation in Southern Punjab (Pakistan): An empirical evidence from the project area of Asian Development Bank. International Research Journal of Finance and Economics, $23,23-32$.

Hulme, D., \& P. Mosley (1996). Finance against poverty. London: Routledge.

Hussain, M., \& Shirazi, N. S. (1995). An analysis of Pakistan's poverty problem from an Islamic perspective. The Pakistan Development Review, 34(4), 857-864.

Kemal, A. R. (1995). Poverty alleviation in Pakistan: An evaluation of public strategies and policies adopted for poverty alleviation. Institute of Policy Studies, Islamabad.

Khandker, S., Samad, H., \& Khan, Z. (1998). Income and employment effects of micro-credit programmes: village level evidence from Bangladesh. Journal of Development Studies, 35I(2), 96-124.

Malik, S. J., \& Nazli, H. (1997). Rural poverty and credit use: Evidence from Pakistan. The Pakistan Development Review, 38(4), 699-716.

Manzoor, Z., \& Saira, A., (2006). Role of Punjab Rural Support Program in increasing economic status and poverty alleviation efforts in rural Faisalabad (Pakistan). Journal of Agriculture and Social Sciences, 2(2), 110-111.

Nawaz, A. (2010). Micro-finance and poverty eeduction: Evidence from a village study in Bangladesh. Journal of Asian and African Studies, 45(6), 670-683.

Noreen, U. (2010). Impact of microfinance on poverty. Unpublished PhD Thesis. Foundation University, Islamabad.

Panjaitan-Drioadisuryo, R. D., \& Cloud, K. (1999). Gender, self-employment and micro programs: An Indonesian case study. The Quarterly Review of Economics and Finance, 39(5) 769-779.

Parker, D., Kirkpatrick, C., \& Theodorakopoulou, C. F. (2008). Infrastructure regulation and poverty reduction in developing countries: A review of the evidence and a research agenda. The Qaurterly Review of Economics and Finance, 48(2), 177-188.

Sabir, H. (2004). Rural poverty alleviation through the empowerment of small farmers in Punjab. Unpublished PhD Thesis. University of Agriculture, Faisalabad.

Saboor, A., Hussain, M., \& Munir, M. (2009). Impact of micro credit in alleviating poverty. Pakistan Journal of Life and Social Sciences, 7(1), 90-97.

Schultz, T.W. (1964). Transforming traditional agriculture. New Haven: Yale University Press.

Shirazi, N., \& Khan, A. (2009). Role of Pakistan Poverty Alleviation Fund's micro credit in poverty alleviation: A case of Pakistan. Pakistan Economic and Social Review, 47(2), 215-228.

Siddiqui, R (2001). Gender dimensions of poverty in Pakistan. Paper presented at the Asia and Pacific Forum on Poverty: Reforming Policies and Institutions for Poverty Reduction. Manila: Asian 
Development Bank.

Waheed, S. (2009). Does rural micro credit improve well-being of borrowers in the Punjab (Pakistan)? Pakistan Economic and Social Review, 47(1), 31-47.

Waheed, S. (2001). Analysis of issues on micro credit - The case of two villages in Punjab. The Pakistan Development Review, 40(4), 723-750. 
